\title{
Erratum to: The use of the Godin-Shephard Leisure-Time Physical Activity Questionnaire in oncology research: a systematic review
}

Steve Amireault ${ }^{1,2^{*}}$, Gaston Godin ${ }^{3}$, Jason Lacombe ${ }^{1}$ and Catherine M. Sabiston ${ }^{1}$

\section{Erratum}

After publication of the original article [1], it was noticed that authors' affiliations were incorrectly specified. Affiliation 1 was incorrectly given as Purdue University, whereas the review was carried out at the University of Toronto.

The updated and correct author affiliations of the original article [1] are presented in this erratum. As a result, the 'Authors' information' and Authors details' sections also should have originally appeared as presented here.

\section{Authors' information}

Steve Amireault is now at Purdue University, Department of Health and Kinesiology, Lambert Fieldhouse, 800 W. Stadium Ave., Room 311A, West Lafayette, IN 47907-2046, USA.

\section{Author details}

${ }^{1}$ Faculty of Kinesiology and Physical Education, Warren Stevens Building, University of Toronto, 55 Harbord St., Toronto, ON M5S 2W6, Canada. ${ }^{2}$ Department of Psychology, Faculty of Arts and Science, PY Building, Concordia University, 7141 Sherbrooke West, Montreal, QC H4B 1R6, Canada. ${ }^{3}$ Faculty of Nursing, Pavillon Ferdinand-Vandry, Université Laval, 1050 Avenue de la Médecine, Quebec City, QC G1V 0A4, Canada.

Published online: 09 March 2016

\section{Reference}

1. Amireault S, Godin G, Lacombe J, Sabiston CM. The use of the Godin-Shephard Leisure-Time Physical Activity Questionnaire in oncology research: a systematic review. BMC Med Res Methodol. 2015;15:60. doi:10.1186/s12874-015-0045-7.

* Correspondence: samireau@purdue.edu

${ }^{1}$ Faculty of Kinesiology and Physical Education, Warren Stevens Building, University of Toronto, 55 Harbord St., Toronto, ON M5S 2W6, Canada ${ }^{2}$ Department of Psychology, Faculty of Arts and Science, PY Building, Concordia University, 7141 Sherbrooke West, Montreal, QC H4B 1R6, Canada
Submit your next manuscript to BioMed Central and we will help you at every step:

- We accept pre-submission inquiries

- Our selector tool helps you to find the most relevant journal

- We provide round the clock customer support

- Convenient online submission

- Thorough peer review

- Inclusion in PubMed and all major indexing services

- Maximum visibility for your research

Submit your manuscript at

www.biomedcentral.com/submit

\section{Biomed Central}

